\title{
Palynology of the upper Barremian and lower Aptian interval in parts of North Bulgaria
}

\author{
Polina Pavlishina \\ Department of Geology, Palaeontology and Fossil Fuels, Sofia University, 15 Tzar Osvoboditel Blvd, 1000 Sofia, Bulgaria; \\ e-mail:polina@gea.uni-sofia.bg.
}

(Accepted in revised form: October 2017)

\begin{abstract}
Upper Barremian and lower Aptian dinoflagellate cyst assemblages have been documented for the first time from five ammonite-controlled sections in Central and Northeast Bulgaria. They include important biostratigraphical markers, such as Rhynchodiniopsis aptiana, Prolixosphaeridium parvispinum, Cerbia tabulata, Lithodinia stoveri and Ctenidodinium elegantulum. The distribution of taxa is generally consistent with published palynostratigraphical schemes, but some differences are noted in this study. The best global markers for the lowermost Aptian interval are represented by the LOs of R. aptiana and C. elegantulum; however, in the sections studied, these taxa consistently occur only within the upper Barremian. The recorded overwhelming dominance of the Classopollis group, together with persistent records of pteridophyte spores, is interpreted as indicative of extremely hot and humid climate, which caused and accompanied the deposition of the OAE 1a in this part of the Tethyan Realm.
\end{abstract}

Pavlishina, P. 2017. Palynology of the upper Barremian and lower Aptian interval in parts of North Bulgaria. Geologica Balcanica 46 (2), 41-45.

Keywords: Barremian, Aptian, dinoflagellate cysts, North Bulgaria.

\section{INTRODUCTION}

The late Early Cretaceous was a time of transition in the nature of ocean-climate system. The BarremianAptian time interval marks the beginning of these late Early Cretaceous geological changes that have been recorded on a global scale. The early Aptian was a time of global warming, leading to enhanced weathering, global ocean anoxia and increasing marine productivity (Leckie et al., 2002). The widespread deposition of an anoxic horizon (OAE 1a) (Selli Level sensu Coccioni et al., 1992) in many Tethyan and Boreal areas may be regarded as a result of these climatic and tectonic (igneous) events of the Barremian/Aptian boundary interval.

The Barremian-Aptian was also a time of rapid radiation and turnover in the marine microphytoplankton (Bujak and Williams, 1979; Leckie et al., 2002) and the terrestrial plants. Extensive dinoflagellate cyst information is available from Barremian and Aptian sections in both the Tethyan and Boreal realms (e.g., Costa and Davey, 1992; Leereveld, 1995; Wilpshaar, 1995; Monteil and Foucher, 1998; Torriceli, 2000; Unida and Patruno, 2016). These studies demonstrated the high biostratigraphic potential of selected dinocyst index-species and their value for wide interregional correlations.

The purpose of the present work is to present for the first time a well-dated dinocyst and sporomorph record from the upper Barremian and lower Aptian interval in five studied sections in North Bulgaria, to estimate key bioevents with correlation value within the dinocyst successions, and to report the terrestrial palynomorphs obtained during this study.

\section{STUDIED SECTIONS}

Five outcrop sections, situated in the Central and Northeast Bulgaria, were chosen for this palynological study, namely sections Butovo, Paskalevets, Dichin, Opaka, and Kostandenets (Fig. 1). They comprise upper Barremian and lower Aptian successions belonging to the Trambesh Formation (comprising clays, marls, and rare thin sandstone beds; sections Butovo and Paskalevets), the Gorna Oryahovitsa Formation (composed of marls with thin interbeds of siltstones; sections Dichin and Opaka) and the Razgrad Forma- 
tion (represented by alternation of clay-rich limestones and marls; section Kostandenets).

These sections have been studied extensively in terms of litho- and biostratigraphy (Nikolov and Stoykova, 1995) and a detailed biostratigraphical framework based on ammonites has been established (Ivanov, 1995; Ivanov and Idakieva, 2013) (Fig. 1). The OAE 1a has also been indicated in the Butovo section (Ivanov and Idakieva, 2013), based on lithological data.

\section{MATERIAL AND METHODS}

All sections were sampled at a normal pilot resolution and more than 25 samples were collected. The obtained palynological assemblages are composed of dinoflagellate cysts, trilete spores, gymnosperm and early angiosperm pollen. The chronostratigraphical framework for the sections established by Ivanov and Idakieva (2013) was utilized in order to estimate the timing of the encountered dinocyst events.

Dinoflagellate cysts and miospores are represented nearly equally in the sediments of the Gorna Oryahovitsa and Razgrad formations, while in the Trambesh Formation miospores dominate over the rest of the palynomorphs.

\section{RESULTS AND DISCUSSION}

\section{Dinoflagellate cyst biostratigraphy}

The dinocyst record is quite representative and comprises more than 30 species. The observed dinoflagellate cyst assemblages reflect a Tethyan, rather than Bo-

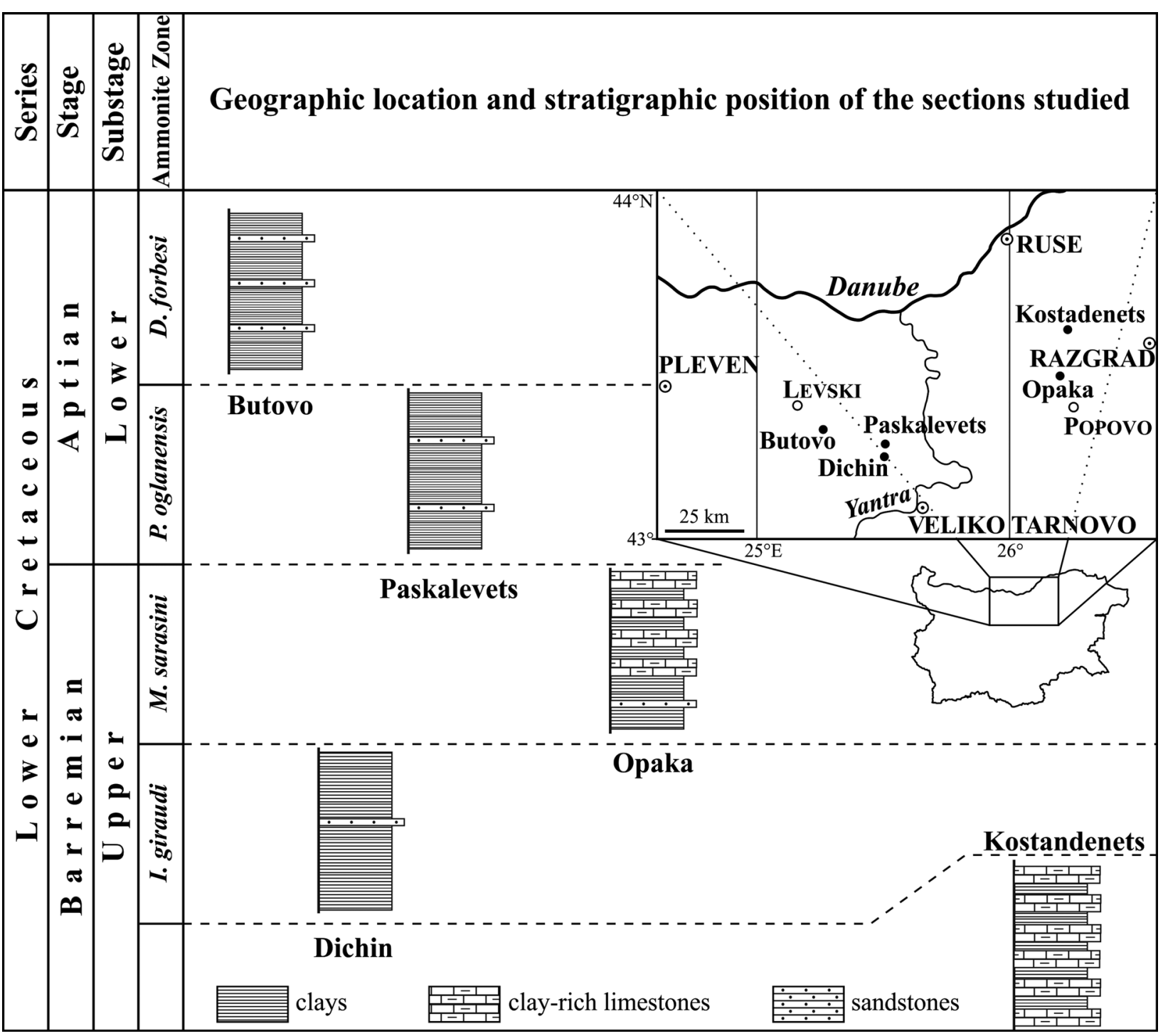

Fig. 1. Studied sections calibrated to the stratigraphical framework elaborated by Ivanov (1995) and Ivanov and Idakieva (2013) with designated geographic location. 
real, character. Therefore, comparison and correlation refer mainly to associations from the Tethyan Realm and the corresponding zonation schemes of Leereveld (1995), Wilpshaar (1995), Monteil and Foucher (1998), Torriceli (2000), and the proposed Barremian/Aptian boundary GSSP at Gorgo a Cerbara, Italy (Unida and Patruno, 2016). The biostratigraphic value of selected taxa was estimated by these correlations, and the results are given below.

1) The prominentoccurrence of Prolixosphaeridium parvispinum, Cerbia tabulata, Achomosphaera neptuni, Lithodinia stoveri, Nexosispinum vetusculum, and Odontochitina operculata characterize the upper Barremian-lower Aptian interval. These taxa were documented in all studied sections and have been estimated as important markers suitable for differentiating the lower Barremian from the upper
Barremian-lowermost Aptian on a wide geographic scale. Torriccelli (2000) recorded the FO of Prolixosphaeridium parvispinum and Odontochitina operculata within the magnetic chron M1 in the Cismon Apticore, Italy, hence in the lower part of the upper Barremian. This correlates with the FOs reported for these species from SE Spain (Leereveld, 1995) and SE France (Wilpshaar, 1995). A similar age has also been documented for these FOs in some ammonitedated sections of the Boreal Realm (Duxbury, 1977; Prossl, 1990), suggesting that they are important biohorizons in the lower upper Barremian of the Northern Hemisphere.

2) The occurrence of Rhynchodiniopsis aptiana and Ctenidodinium elegantulum is continuous and abundant in the upper Barremian successions, but these taxa were not documented in the lower Aptian sediments
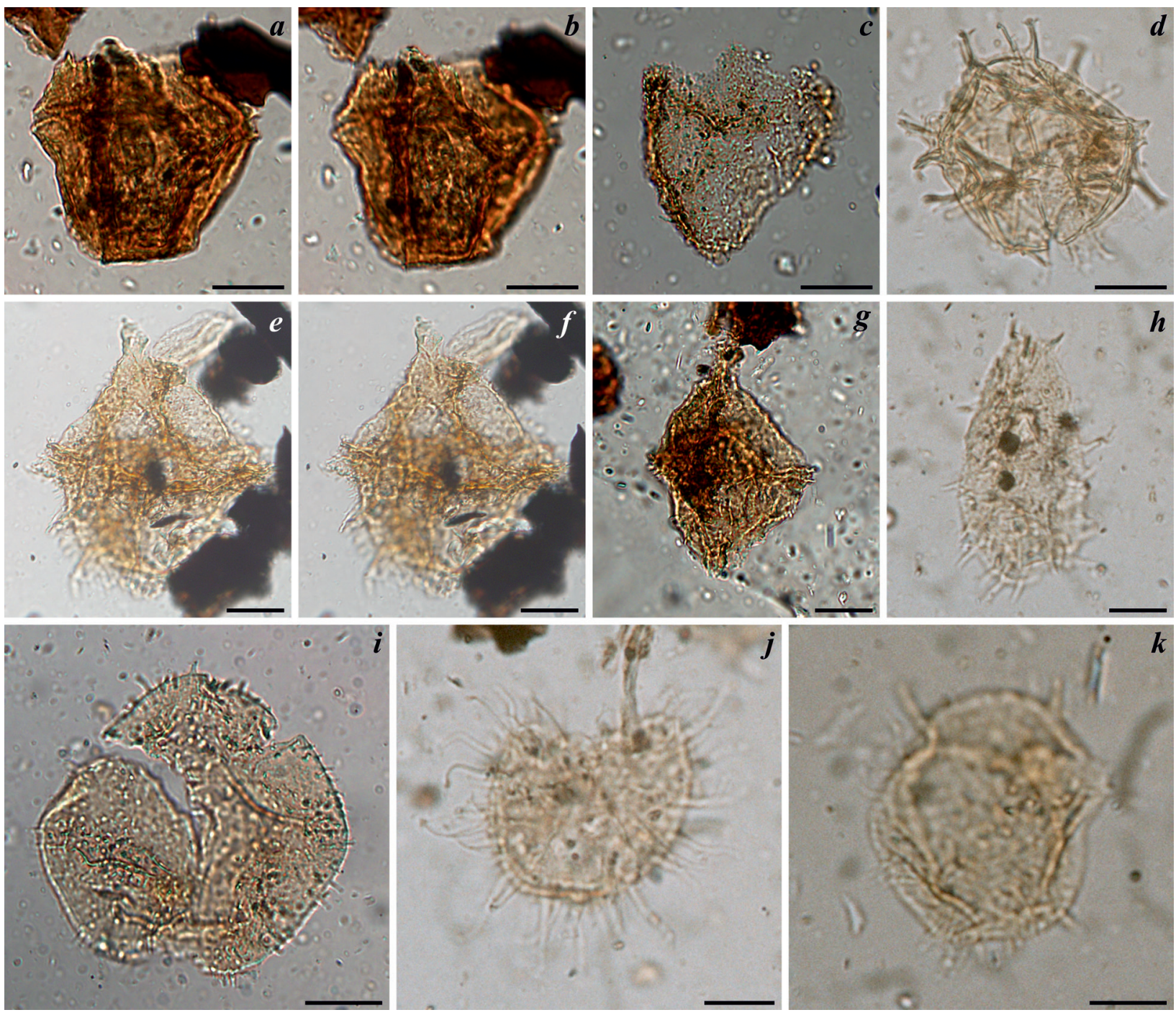

Fig. 2. Photomicrographs of important dinoflagellate cyst species recovered from the studied sections. Scale bar $10 \mu \mathrm{m}$. $a, b)$ Lithodinia stoveri; c) Sentusidinium sp.; d) Achomosphaera neptuni; e, f) Rhynchodiniopsis aptiana; $g$ ) Rhynchodiniopsis cladophora; $h$ ) Prolixosphaeridium parvispinum; $i$ ) Cerbia tabulata; $j$ ) Nexosispinum vetusculum; $k$ ) Ctenidodinium elegantulum. 

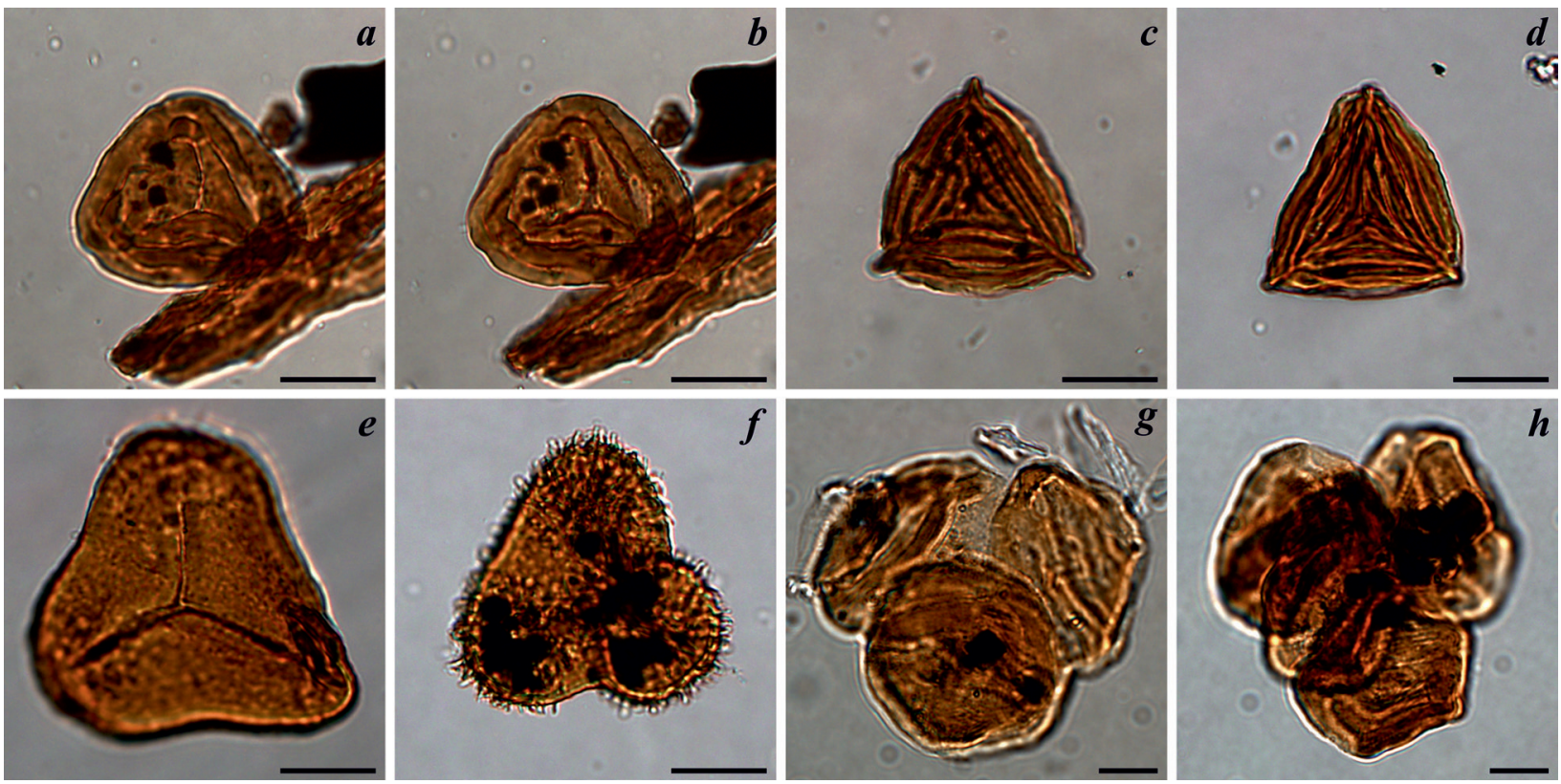

Fig. 3. Photomicrographs of important spores and pollen recovered from the studied sections. Scale bar $10 \mu \mathrm{m}$. a, b) Bikolisporites toratus; $c, d)$ Appendicisporites spp.; e,f) Trilobosporites spp.; $g, h$ ) Classopollis torosus (tetrads).

studied in the sections Butovo and Paskalevets. These dinoflagellate cysts are typically Barremian species in the Tethyan Realm and display their range top in the lowermost Aptian. Torricelli (2000) noted the LO of $R$. aptiana in the Cismon Apticore at the base of the magnetic chron M0, immediately above the Barremian/Aptian boundary, placed by Erba et al. (1999). Leereveld and Berthrou (1990) calibrated this event as well and considered it a reliable biohorizon for basal Aptian sediments not only for the Tethyan Realm but also for the Northern Hemisphere. Unida and Patruno (2016) documented the LO of R. aptiana in the Barremian/Aptian boundary GSSP at Gorgo a Cerbara (Italy) within the lower Aptian Selli Level, $1.35 \mathrm{Myr}$ after the magnetostratigraphycally defined boundary, and concluded that its LO does not define the Barremian/Aptian boundary, but is a global marker for the lowermost Aptian. According to Stover et al. (1996), the LO of C. elegantulum also corresponds to the lower Aptian in the Tethyan and Boreal realms.

In sections Butovo and Paskalevets, $R$. aptiana and C. elegantulum are not present in the lowermost Aptian succession, and their top range is within the upper Barremian M. sarasini ammonite Zone, thus supporting their global value for the upper Barremian interval.

3) The upper Barremian-lower Aptian assemblages are also completed by the following characteristic dinocyst taxa: Batiacasphaera macrogranulata, $B$. saidensis, Prolixosphaeridium conulum, Chlamidophorella nyei, Sentusidinium spp., and Tanyosphaeridium spp.

\section{Terrestrially derived palynomorphs}

Pteridophyte spores are present in considerably high diversity and are typically represented by taxa assigned to the genera Appendicisporites, Cicatricosisporites, Bikolisporites, Trilobosporites, and Concavisporites. Gymnosperms predominate the assemblages. An overwhelming dominance of the $\mathrm{Cl}$ assopollis group is recorded in all sections, including the OAE 1a level throughout the Butovo section, representing up to $40-50 \%$ of the palynoflora. The Classopollis pollen often occurs in tetrads due to the exceptionally good preservation conditions. Such dominance, together with the persistent records of Pteridophyte spores, is a typical feature of the late Early Cretaceous low-latitude assemblages (Unida and Patruno, 2016). In the sections studied herein, their presence once more indicates the extremely hot and humid climate that caused and accompanied the deposition of the OAE 1a anoxic layer.

\section{CONCLUSIONS}

Upper Barremian and lower Aptian dinoflagellate cyst assemblages have been documented for the first time from five ammonite-controlled sections in the Central and Northeast Bulgaria. They include important biostratigraphical markers, such as Rhynchodiniopsis aptiana, Prolixosphaeridium parvispinum, Cerbia tabulata, Lithodinia stoveri, and Ctenidodinium ele- 
gantulum. The distribution of taxa is generally consistent with published palynostratigraphical schemes, but some differences are noted in this study. The best global markers for the lowermost Aptian interval are represented by the LOs of $R$. aptiana and C. elegantulum. Our sections confirm their global value only for the upper Barremian.

The recorded overwhelming dominance of the Classopollis group, together with the persistent records of pteridophyte spores, is interpreted as indicative of the extremely hot and humid climate that caused and accompanied the deposition of the OAE 1a in this part of the Tethyan Realm.

\section{Acknowledgements}

I express my sincere gratitude to Prof. Marin Ivanov (Sofia University) for fruitful joint fieldwork, as well as for his final support and valuable contribution on the manuscript. Financial support from the Synthesys Program at the National History Museum, Stockholm, is gratefully acknowledged.

\section{REFERENCES}

Bujak, J.P., Williams, G.L. 1979. Dinoflagellate diversity through time. Marine Micropaleontology 4, 1-12.

Coccioni, R., Erba, E., Premoli-Silva, I. 1992. Barremian-Aptian calcareous plankton biostratigraphy from the Gorgo Cerbara section (Marche, central Italy) and implications for plankton evolution. Cretaceous Research 13 (5-6), 517-537.

Costa, L.I., Davey, R.J. 1992. Dinoflagellate cysts of the Cretaceous System. In: Powell, A.J. (Ed.), A stratigraphic index of dinoflagellate cysts. Chapman \& Hall, London, 99-153.

Duxbury, S. 1977. A palynostratigraphy of the Berriasian to Barremian of the Speeton Clay of Speeton, England. Palaeontographica B 160, 17-67.

Erba, E., Channel, J.E.T., Claps, M., Jones, O., Larson, R., Opdyke, B., Premoli Silva, I., Riva, A., Salvini, G., Torricelli, S. 1999. Integrated stratigraphy of the Cismon Apticore (southern Alps, Italy); a "reference section" for the Barremian-Aptian interval at low latitudes. Journal of Foraminiferal Research 29 (4), 371-391.

Ivanov, M. 1995. Stratigraphy of the Barremian and Aptian in southern part of the Moesian Platform of Central-North Bulgaria. Review of the Bulgarian Geological Society 56 (1), 37-46.

Ivanov, M., Idakieva, V. 2013. Lower Aptian ammonite biostratigraphy and potential for further studies of OAE $1 \mathrm{a}$ in Bulgaria. Cretaceous Research 39, 47-69.

Leckie, R.M., Bralower, T.J., Cashman, R. 2002. Oceanic anoxic events and plankton evolution: Biotic response to tectonic forcing during the mid-Cretaceous. Paleoceanography 17, 3:10.129/2001PA000623.

Leereveld, H. 1995. Dinoflagellate cysts from the Lower Cretaceous Rio Argos succession (SE Spain). LPP Foundation, Utrecht, $175 \mathrm{pp}$.

Leereveld, H., Berthrou, P.Y. 1990. L'Apport de l'étude des kystes de dinoflagelles à la stratigraphie des Terrains
Hauteriviens à Albiens. Région de Lisbonne (Portugal). Comunicações dos Serviços Geológicos de Portugal 72 (1), 119-128.

Monteil, E., Foucher, J.C. 1998. Cretaceous biochronostratigraphy. In: De Graciansky, P., Hardenbol, J., Jacquin, T., Vail, P. (Eds), Mesozoic and Cenozoic Sequence Stratigraphy of European basins. SEPM Special Publication 60, Tulsa, 1-60.

Nikolov, T., Stoykova, K. 1995. Notes on the lithostratigraphy of the Lower Cretaceous in the western part of the Northeastern Bulgaria. Annual of Sofia University, Faculty of Geology and Geography 84, 5-17.

Prossl, K.F. 1990. Dinoflagellaten der Kreide - Unter Hauterive bis Ober Turon - im Niedersächsischen Becken. Stratigraphie und Fazies in der Kembohrung Konrad 101 sowie einiger anderer Bohrungen in Nordwestdeutschland. Palaeontographica B 218, 93-191.

Stover, L.E., Brinkhuis, H., Damassa, S.P., Verteuil, L. Helby, R., Monteil, E., Partridge, K. 1996. Mesozoic-Tertiary dinoflagellates, acritarchs ana prasinophytes. In: Jansonius, J., McGregor, D.C. (Eds), Palynology: principles and application. American Association Starigraphic Palynologists Foundation, New York, 641-750.

Torricelli, S. 2000. Lower Cretaceous dinoflagellate cyst and acritarch stratigraphy of the Cismon APTICORE (Southern Alps, Italy). Review of Palaeobotany and Palynology 108, 213-266.

Unida, S., Patruno, S. 2016. The palynostratigraphy of the Upper Maiolica, Selli Level and the Lower Marne a Fucoidi units in the proposed Barremian/Aptian (Lower Cretaceous) GSSP stratotype at Gorgo a Cerbara, Umbria-Marche Basin, Italy. Palynology 40 (2), 230-246.

Wilpshaar, M. 1995. Direct stratigraphic correlation of the Vercors carbonate platform in SE France with the Barremian stratotype by means of dinoflagellate cysts. Cretaceous Research 16, 273-281. 